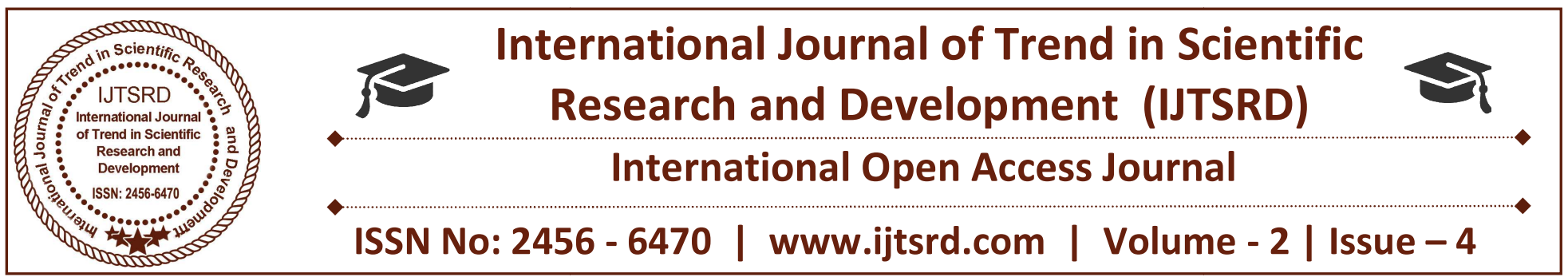

\title{
A Case Study for Optimum Sizing and Selection of Components in HRERs based Power Sysetm
}

\author{
Reyaz Ahmed Bafanda \\ M.Tech Scholar, Electrical Engineering Department, \\ Yamuna Institute of Engineering \& Technology, Gadhauli, Yamunanagar, Haryana, India
}

\begin{abstract}
The demand of electricity in rural India is increased two fold in the last decade and this demand has been met by the electricity grid extension so far. But the cost of extension of grid is very high and also depends upon land location, distance to be covered and more importantly size of the load. The recent researches show that adding the renewable energy resources to the system at the load centre makes the system less costly and environment friendly. The different configurations are compared and the selection of optimum configuration is based on the least value of cost of energy (COE) and net present cost (NPC) along with the highest value of renewable fraction (RF) and lowest harmful emissions (CO2) using HOMER (Hybrid Optimization Model for Electric Renewables) software is presented. A village location, Kotali Charkan ( $32^{\circ} 37^{\prime} 0^{\prime \prime}$ North, $74^{\circ} 50^{\prime} 00^{\prime \prime}$ East) in Jammu and Kashmir state of India is chosen for the system under the study, the hydro, solar and wind resources are available almost throughout the year on the selected village location.
\end{abstract}

Keywords: HOMER, RERs, optimum sizing, Hybrid system

\section{INTRODUCTION}

In recent decades, rapid population growth and technological development have resulted in to more consumption of energy, especially in electricity sector. Moreover, there are many parts of the world particularly in rural areas in developing countries which have limited or no access to electricity. It is also reported that rural electrification is very important for development of the rural areas so as to obtain economic growth, poverty elimination, employment generation and improvement of living standard of the villages. According to the Census held in 2011 in India, 0.83 billion out of 1.21 billion resides in rural areas and out of which around $44 \%$ population does not have the access of grid [1]. In order to overcome these problems, electricity generation has to be increased. In India, a large part of the electricity is produced by fossil fuel resources [2]. As on June 30,2017 India has total installed capacity of $329.23 \mathrm{GW}$ and coal and diesel based power plants has $66.7 \%$ share [2]. To electrify the rural areas and to reduce the dependency on conventional energy resources, Government of India has started various programmes like as Remote Village Electrification Programme (RVEP), Rajiv Gandhi Grameen Vidyutikaran Yojana (RGGVY), etc. [1]. Government has also revised the target of solar power projects from $20 \mathrm{GW}$ to $100 \mathrm{GW}$ by $2021-22$ under Jawaharlal Nehru National Solar Mission (JNNSM) as of rapid rise in power production from solar power plants [1].

The electrification of rural area by grid extension in India costs about $8000 \$ / \mathrm{km}$ to $10000 \$ / \mathrm{km}$ and it can cost more in difficult terrains. Even if the grid is extended and source of power is secured, there are huge transmission and distribution (T\&D) losses occurs. So electrification of rural areas by conventional grid extension method is not a viable option. This problem can be solved by distributed generation where T\&D losses can be minimized and also the RF can be increased. In the past decade, many researchers studied about the more reliable renewable energy sources (RES) based system in combination of 
other energy systems to form a single system i.e. hybrid renewable energy systems (HRES) [3]. The COE decreases and reliability of the system increases if the different combinations of RESs are used together, as they support each other in cost-effective way. For example in rainy season the solar energy is not available but hydro energy is available to support and as many energy sources are available, so the source with least COE can be chosen.

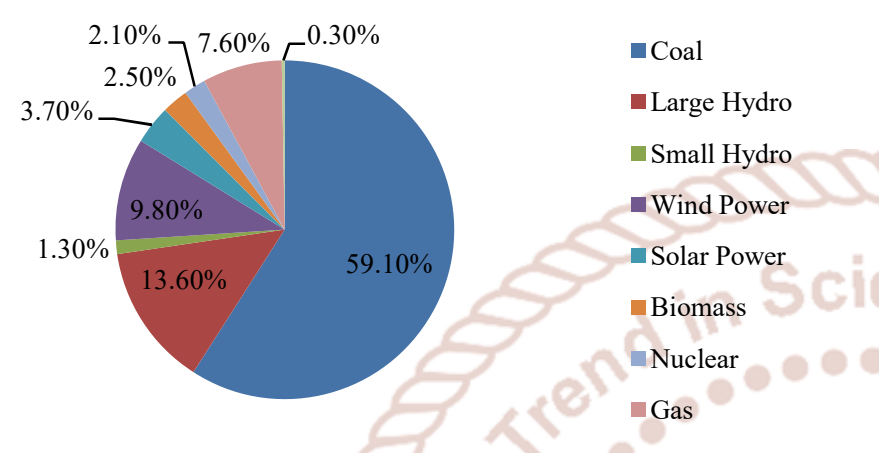

Fig1. Installed capacity by source in India as on 30 June 2017 [2].

In the past decade, many researchers studied about the more reliable renewable energy sources (RES) based system in combination of other energy systems to form a single system i.e. hybrid renewable energy systems (HRES) [3]. The COE decreases and reliability of the system increases if the different combinations of RESs are used together, as they support each other in cost-effective way. For example in rainy season the solar energy is not available but hydro energy is available to support and as many energy sources are available, so the source with least COE can be chosen.

Malik has conducted a study to assess the potential of renewable energies in Brunei Darussalam. From the study, the author identified the availability of renewable energies that could be utilized [4]. A review is provided by Bhattacharyya [5] for off-grid PV systems in regarding to the rural electrification of developing countries in South Asia, South East Asia, Latin America and Africa. Sathans and Om Krishan [6] provided a comparison of COE and NPC of a grid integrated hybrid system of a small village when RERs are added to the system using HOMER simulation tool. The results show the significant drop in COE and power outage hours. Fantidis et al. [7] studied the potential of solar radiation and solar power plants at 46 location of Greece and found that solar power plants could avoid on an average 20.19 tons of greenhouse gases emission. Chade et. al [8] conducted a case study of islanded location and compared the COE of different configurations applying HOMER software and hydrogen energy storage system with wind turbine found to be a feasible solution.

The village Kotali Charkan in Jammu \& Kashmir state of India is selected for achieving this objective. The paper is organized as follows: Section I presents the introduction of the study. Section II presents system modelling and section III provides the results. The paper is concluded in section IV

\section{System Modelling}

HOMER software developed by NREL (National Renewable Energy Laboratory, USA) is used for finding the optimum configuration and assessing the techno-economic viability of HRES based system. Fig. 2 shows the schematic of the methodology used for this study. The location for study is identified and detailed assessment of the load profile and available RERs are explained further in this section.

The data collected is fed into the HOMER simulation tool and optimum configuration is found. HOMER compares the different RER based configurations and different constraints and sensitivity analysis are done for optimize the system design.

A small village Kotali Charkan in Jammu district in Jammu and Kashmir State of India is considered for this study. The details about the village demographic particulars are given in Table I. The village is situated near river Chenab within the distance of 1.5 kilometers. The water flow is continuous throughout of the years in the river. The selected village is mostly of flat terrain and receives average solar irradiance of $5.15 \mathrm{kWh} / \mathrm{m}^{2} /$ day. The average wind speed in the village is $4.3 \mathrm{~m} / \mathrm{sec}$. The drinking water facilities in the village are in the form of tube well and hand pumps. The village has total 1325 hectare of agricultural land and tube-wells are used for irrigation purpose.

\section{USER LOAD ASSESSMENT}

A. Primary load-I: This includes the load of the domestic appliances. The total primary load calculated for summers is $1151.87 \mathrm{kWh} /$ day. The domestic load of the village in the winter season is $435.435 \mathrm{kWh} /$ day. The calculated average annual consumption per household is $2.1 \mathrm{kWh} /$ day. Peak 
load for the summer is $197.29 \mathrm{~kW}$ and average load is $48 \mathrm{~kW}$ which gives the load factor of 0.24 . As the winter load is less than half of the summer load so there is no need for calculating the peak load for the winters.

B. Primary load-II: This load includes the load of shops in the village, street lights, temples, primary health centre and schools. Average load calculated under the primary load-II comes out to be 95.35 $\mathrm{kWh} /$ day in summer and in the winter season it is $78.15 \mathrm{kWh} /$ day. The peak demand is $13.5 \mathrm{~kW}$ and average demand is $3.978 \mathrm{~kW}$ giving a load factor of 0.29 .

\section{TABLE1: Details ABOUT THE VILlAGE KotALI}

\begin{tabular}{|c|c|}
\hline Particulars & Details \\
\hline Village Name & Kotali Charkan \\
\hline District & Jammu \\
\hline State & $\begin{array}{l}\text { Jammu and } \\
\text { Kashmir }\end{array}$ \\
\hline Country & India \\
\hline Latitude & $32.37^{\circ}$ \\
\hline Longitude & $74.50^{\circ}$ Trend \\
\hline Elevation & $555 \mathrm{~m}$ \\
\hline Nearby River & 01 \\
\hline Area of the village & 325 Hectare \\
\hline Total House & 332 \\
\hline Total Population & 1592 \\
\hline & \begin{tabular}{l|l}
$\mathrm{M}$ & $\mathrm{F}$ \\
859 & 733
\end{tabular} \\
\hline $\begin{array}{l}\text { Educational facilities (No. of } \\
\text { schools) }\end{array}$ & 03 \\
\hline $\begin{array}{l}\text { Medical facilities (No. of } \\
\text { primary health centres) }\end{array}$ & 01 \\
\hline
\end{tabular}

The total consumption of the village is 1247.2 $\mathrm{kWh} /$ day in the summers and in the winters it is $513.585 \mathrm{kWh} /$ day.

\section{A. Resources assessment}

Solar, wind, bio-gas, microhydro resources and grid are used in the simulation under this study. The resources are carefully chosen by taking into account the geographical conditions of the selected location. In the next part of this section, these sources are described in detail. The electricity from the grid is purchased at the rate $\$ 0.1 / \mathrm{kWh}$ with sell back price at $\$ 0.05 / \mathrm{kWh}$.

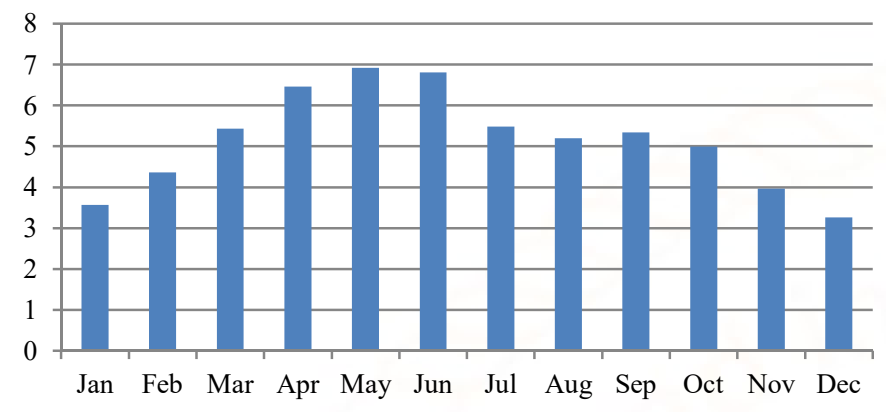

Fig. 2. Solar radiation at the selected location.

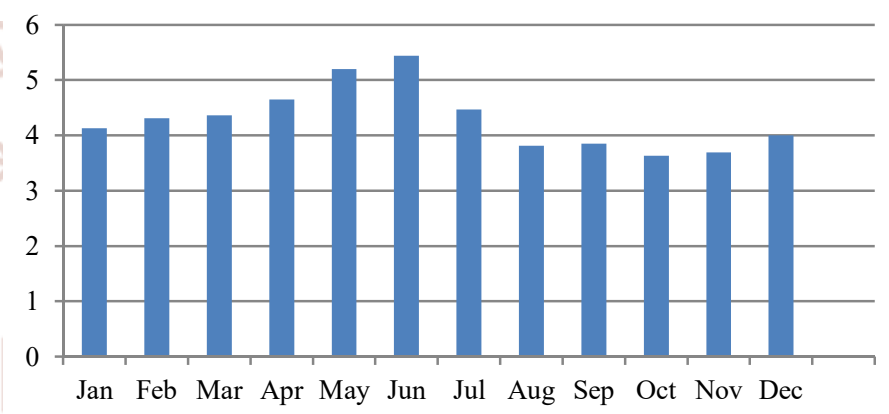

Fig. 3. Wind Speed at the selcted loaction.

\section{1) Hydro Power}

As mentioned previously, the study area is surrounded by the Chenab River. The river has length of $960 \mathrm{~km}$ and has maximum water discharge of 15733 cusec. Augmentation canal is the branch of Western Yamuna canal. It has maximum water discharge of 28273 cusec.

The village is well connected with the grid, but there is $8-10$ hours of power outage per day. So in the simulation we have considered the 9 hours power outage per day and assuming 10 failures in a year, each failure has 2 hours of repairing time.

\section{SIMULATION RESULTS}

As mentioned above, the main aim of this study is to propose the optimal grid integrated hybrid power system which can provide uninterrupted power supply to the residents of the selected location as well as enhance the renewable energy sources contribution to the system. The proposed configuration of the system is simulated in HOMER software for economical and technical analysis. Implementation of the model using HOMER simulation tool is shown in Fig. 4. 
International Journal of Trend in Scientific Research and Development (IJTSRD) ISSN: 2456-6470

Table II. Estimated load for the selected location.

\begin{tabular}{|c|c|c|c|c|c|c|c|}
\hline \multirow[b]{2}{*}{$\begin{array}{l}\text { Sr. } \\
\text { No. }\end{array}$} & \multirow[b]{2}{*}{ Load } & \multirow[b]{2}{*}{$\begin{array}{l}\text { No. in } \\
\text { Use }\end{array}$} & \multirow{2}{*}{$\begin{array}{l}\text { Power } \\
\text { (Watts) }\end{array}$} & \multicolumn{2}{|c|}{ Summers (A pril-October) } & \multicolumn{2}{|c|}{ Winters (November-March } \\
\hline & & & & Hours/Day & Wh/Day & Hours/Day & Wh/Day \\
\hline \multicolumn{8}{|c|}{ Domestic appliances load } \\
\hline & CFLs & 04 & 20 & 06 & 480 & 07 & 560 \\
\hline 2. & CFLs & 02 & 10 & 05 & 100 & 06 & 120 \\
\hline 3. & Ceiling Fans & 02 & 50 & 10 & 1000 & 00 & 00 \\
\hline 4. & TVs & 01 & 75 & 03 & 225 & 03 & 225 \\
\hline 5. & Water pumps & 01 & 500 & 01 & 500 & 0.5 & 250 \\
\hline 6. & Refrigerators & & & 06 & & 00 & 00 \\
\hline & Total & & & & & & 1155 \\
\hline A. & No. of house & 332 & 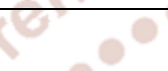 & & 1151735 & & 435435 \\
\hline \multicolumn{8}{|c|}{ Commercial purpose, temples and street light load } \\
\hline 1. & Shops & 10 & 600 & 10 & 60000 & 08 & 48000 \\
\hline 2. & Temples & 02 & 500 & atto 06 & 6000 & 06 & 6000 \\
\hline 3. & Street lights & 30 & 50 & $\operatorname{lnol} \| 10 \mathrm{Sc}$ & ก115000 & 12 & 18000 \\
\hline C. & Total & & & 81000 & & 0 & 72000 \\
\hline \multicolumn{8}{|c|}{ Schools and primary health centre load } \\
\hline 1. & CFLs & 40 & $20 \mathrm{IS}$ & $N=2026=$ & 1600 & 03 & 2400 \\
\hline 2. & Ceiling Fans & 30 & 50 & 06 & 9000 & 00 & 00 \\
\hline 3. & Computers & 03 & 250 & 05 & 3750 & 05 & 3750 \\
\hline C. & Total & & & & & & 6150 \\
\hline
\end{tabular}

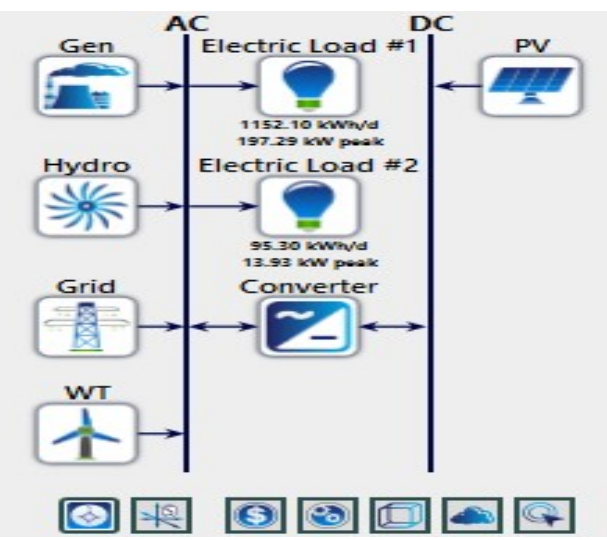

Fig. 4 Implimentation of model in HOMER software.

\section{Simulation configurations}

Five different configurations of the integrated hybrid system have been considered. The simulation time span is considered as one year on hourly basis. The simulation results for each configuration are discussed as under:

a) Configuration 1: Grid and Microhydro resource: After the simulation for this configuration, the cost of energy (COE) was found to be $\$ 0.0759$. Out of total supply $22 \%$ is supplied by grid and $78 \%$ from the microhydro source. The surplus energy i.e. 37000 $\mathrm{kWh} /$ year is sold back to the grid in the months of 
August and September. Net present cost (NPC) is $\$ 483192$.

\section{b) Configuration 2: Grid, Microhydro and Wind resources:}

Optimum sizes of the wind turbine and microhydro, as per the simulation, are found to be $30 \mathrm{~kW}$ and 92 $\mathrm{kW}$ respectively. The COE for this combination is $\$ 0.091 / \mathrm{kWh}$ which is higher than the previous combination mainly due to the initial cost of the wind turbine.

\section{c) Configuration 3: Grid, Biogas, Wind and Microhydro:}

For this configuration, the optimum sizes for the different components are: Biogas generator: $40 \mathrm{~kW}$, Wind turbine $30 \mathrm{~kW}$, microhydro $92 \mathrm{~kW}$. The renewable energy penetration for the system is $72.3 \%$ and rest of the demand is met by the grid. The COE for the combination comes out to be $\$ 0.0724 / \mathrm{kWh}$. In this combination also the surplus energy in the months of August and September (due to good water flow in the rainy season) is supplied back to the grid.

d) Configuration 4: Grid, $P V$, Wind and Microhydro: The COE for this combination is $\$ 0.089 / \mathrm{kWh}$. Renewable energy share is $34.5 \%$ and the optimum sizes for Photovoltaic, Wind turbine and microhydro turbine are $30 \mathrm{~kW}, 40 \mathrm{~kW}$ and $92 \mathrm{~kW}$ respectively. e) Configuration 5: Grid, PV, Wind, Microhydro and Biogas resources:

In this configuration of the system, all the renewable sources of energy are selected. The renewable energy share, as per the simulation, comes out to be $77.2 \%$. As the renewable energy share is increased the $\mathrm{COE}$ is reduced down to $\$ 0.0698 / \mathrm{kWh}$. There is $0 \%$ power outage and the COE is also minimum, so the main aim of this work is demonstrated. Fig. 5. shows power produced by each component in the configuration As the dependence on the grid is reduced in this configuration, $830015 \mathrm{kWh}$ of energy is supplied back to the grid. This helps in the reduction of $\mathrm{COE}$ significantly.

Fig. 6 shows the waveforms of energy produced by RERs and total demand for a week in the month of August, where it is found that the RERS are serving most of the load.

Fig. 7 shows the cost summary of the grid integrated hybrid system under optimum configuration. The largest portion of the capital is used in the bio-gas system, mainly operating \& maintenance cost. Wind turbine has high installation cost. The grid cost is very low as the surplus energy is supplied back to the grid in the rainy season and in the winters when demand is low. Although in the summers energy is purchased from the grid.

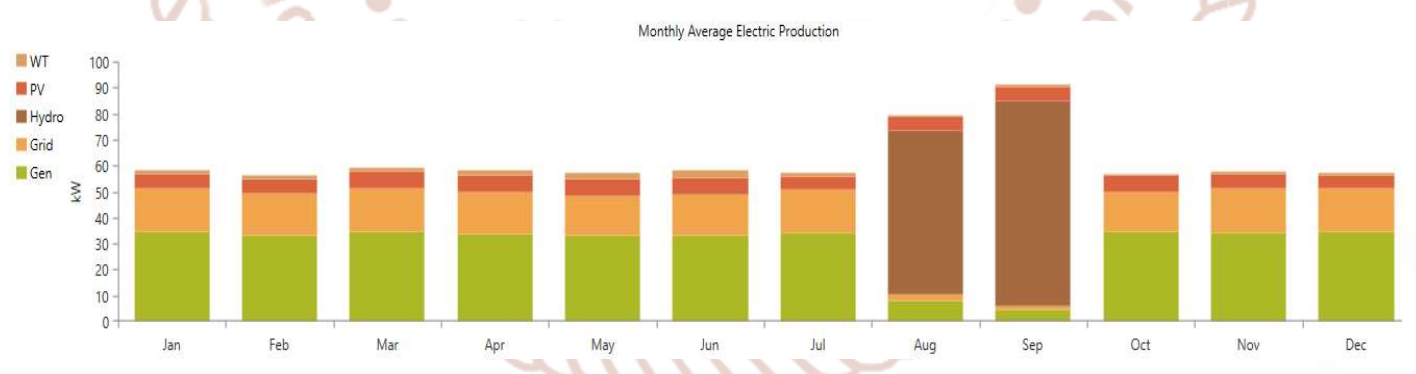

Fig. 1. Power generated by different resources.

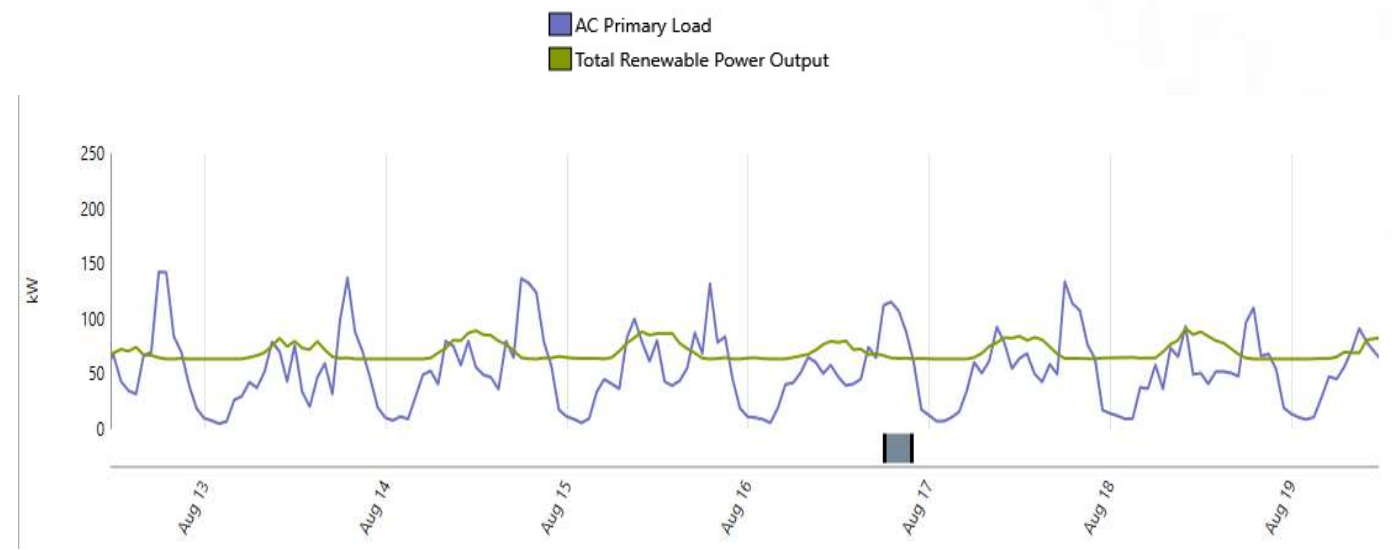

Fig. 2. Plot of demand versus renewable energy resources output. 


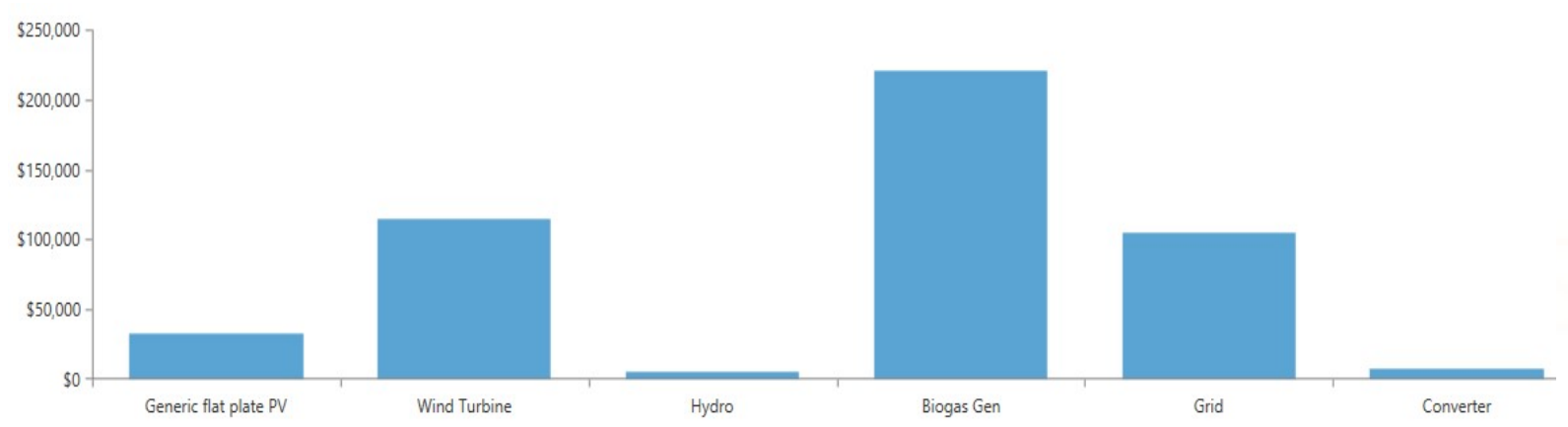

Fig. 3. Cost summary of the grid integrated hybrid system.

\section{Conclusions}

In this paper technical and economical analysis of grid integrated hybrid power system is carried out for the village Kotali Charkan in Jammu district of Jammu and Kashmir state, India. The data is collected from the selected location for load assessment and resources assessment. Five different configurations of RERs combination are simulated using HOMER software. From the results obtained from the different combinations, Grid-PV-Microhydro-Wind-Biogas combination is found to be most economical with COE $\$ 0.0698 / \mathrm{kWh}$ as compared to $\$ 0.1 / \mathrm{kWh}$ when purchased from the grid. The demand is met $100 \%$ at all the time during the year. Optimum configuration of the system consists of $30 \mathrm{~kW}$ PV system, $30 \mathrm{~kW}$ wind turbine, $92 \mathrm{~kW}$ microhydro turbine and $40 \mathrm{~kW}$ biogas generator.

\section{References}

1) Central Electricity Authority, Ministry of Power, Government of India. Retrieved 15 December 2015.

2) Kamalapur G, Udaykumar R. "Rural electrification in India and feasibility of photovoltaic solar home systems," International Journal of Electrical Power Energy System, 2011, vol. 33 (3), pp.594-9.

3) Hafez O, Bhattacharya K. "Optimal planning and design of a renewable energy based supply system for microgrids," Renewable Energy, 2012, vol.45, pp.7-15.

4) Kanase-Patil AB, Saini RP, Sharma MP. "Integrated renewable energy systems for off grid rural electrification of remote area. Renewable Energy,2010, vol. 35, pp.342-1349.

5) Anurag Chauhan, RP Saini. "Techno-economic feasibility study on Integrated Renewable Energy System for an isolated community of India," Renewable and Sustainable Energy Reviews, 2016, vol. 59, pp. 388-405.
6) M. Farrokhifar. "Optimal operation of energy storage devices with RESs to improve efficiency of distribution grids; technical and economical assessment," Electrical Power and Energy Systems, 2016,vol. 74, pp. 153-161.

7) Dalwadi P,Shrinet V, Mehta CR, Shah P. "Optimization of solar-wind hybrid system for distributed generation.'In:Proceedings of the Nirma University International Conference on Engineering (NUiCONE),2011.

8) Nandi SK, Ghosh HR. "Awind-PV-battery hybrid power system at Sita Kunda in Bangladesh. Energy Policy, 2009, vol.37, pp. 3659-64.

9) El-Mnassri M, Leger AS. "Standalone photovoltaic solar power generation system: a case study for a remote location inTunisia,2010.

10) Sreeraj ES,Chatterjee K, Bandyopadhyay S."Design of isolated renewable hybrid powersystems," Solar Energy, 2010, vol. 84, pp.1124-36.

11) Askari IB, Ameri M. "Techno-economic feasibility analysis of stand-alone renewable energy systems (PV/batttery,Wind/battery and Hybrid PV/wind/bat) in Kerman, Iran. Energy Sources Part B, 2011, vol.7, pp.45-60.

12) Www.garv.gov.in/assets/uploads/reports/statesnap s/J\%K.pdf [accessed on 15/04/2018]

13) https://eosweb.larc.nasa.gov/sse $\quad$ [accessed 15/04/2018].

14) http://india-wris.nrsc.gov.in/ [accessed on 16/04/2018].

15) Ankit Bhatt, MP Sharma, RP Saini. "Feasibility and sensitivity analysis of an off-grid micro hydro-photovoltaic-biomass and biogas-dieselbattery hybrid energy system for a remote area in Uttarakhand state, India," Renewable and Sustainable Energy Reviews, 2016, vol. 61, pp. 53-69. 


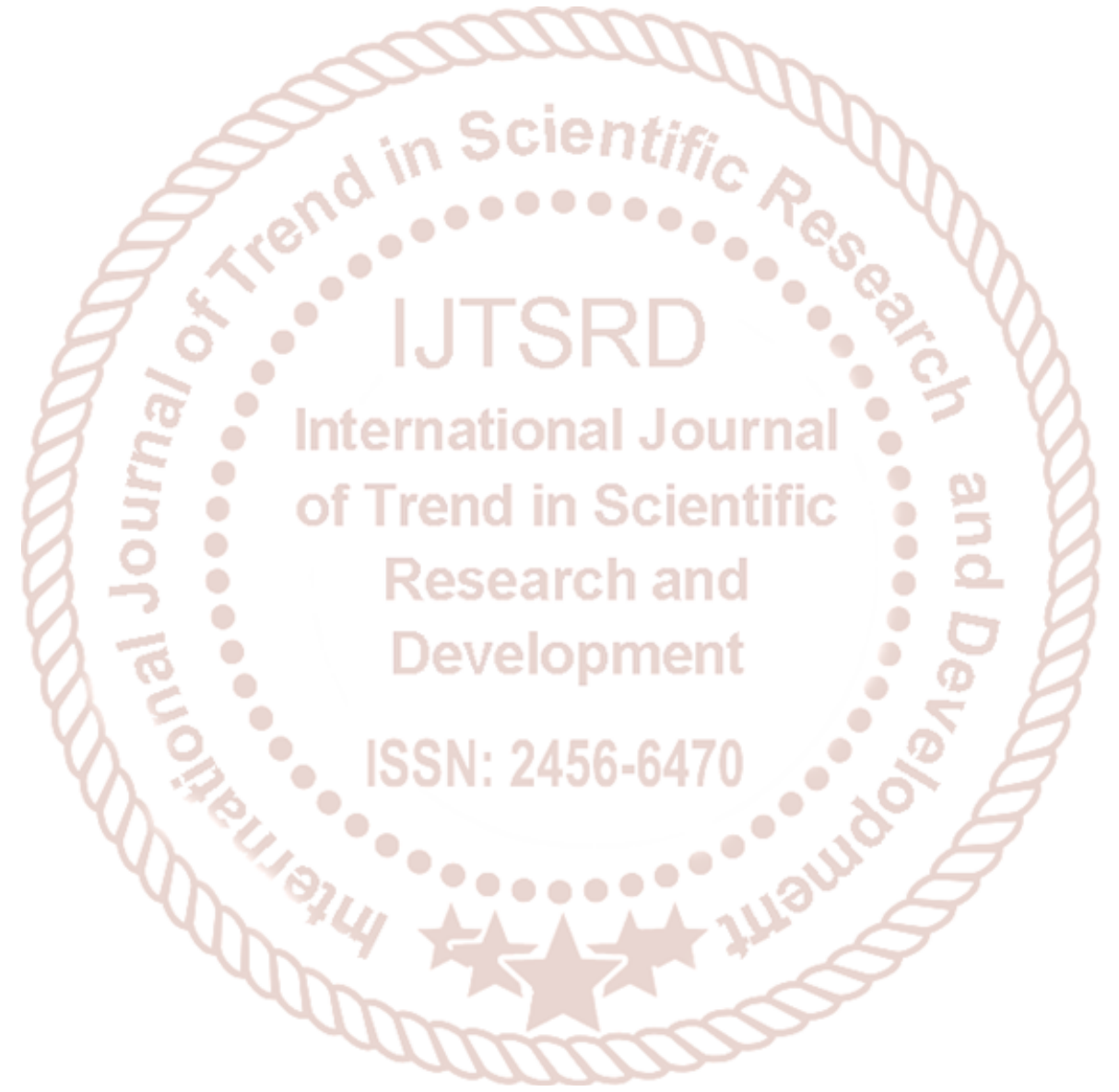

